\title{
THE PIANO FANTASY IN THE CREATIVE WORK OF THE VIENNESE CLASSICS
}

\section{Pogoda Elena ${ }^{1}$}

DOI: https://doi.org/10.30525/978-9934-571-89-3_70

The fantasy - the expression of human creativity - is an integral component of the historical process of the development of art. Formed as a musical genre by the 16th century $[7 ; 11]$, the fantasy has retained its significance until today. The variety of forms, types of content, developed by the fantasy in the process of its historical development, interacted with the complex of those stable features that saved the genre from disintegration, from absorption by other genre forms. The historical epoch of the development of the genre chosen for the analysis (the end of the 18th century and the beginning of the 19 century), a certain instrumental "slice", contains a range of research problems that are relevant to the modern musicology. They are associated with the need to establish the historical specificity of the genre and to detect differences in its individual-style interpretations.

The piano fantasies by V.A. Mozart were created in the last period of his creativity, and they culminate his heritage. The 1782 fantasy trilogy (Fantasy and Fugue C-dur 394 KV, Fantasy c-moll 396 KV and d-moll 397 KV) coincided with the beginning

\footnotetext{
${ }^{1}$ Kharkiv National Kotlyarevsky University of Arts, Ukraine
} 
of the mature stage in the composer's work; Fantasy and Sonata c-moll of 1785 $(475 \mathrm{KV})$ - with the time of the creation of the opera masterpieces (the end of "The Marriage of Figaro" and the beginning of the work on "Don Juan"); Fantasies fmoll $(594 \mathrm{KV})$ and $(608 \mathrm{KV})$ - with the last year of V.A. Mozart's life. The composer turns to the genre of the fantasy, reaching absolute maturity and perfection of the creative style.

In the piano fantasies by V.A. Mozart there is a process of deepening and expanding the lyrical and dramatic spheres of imagery, which F.E. Bach preferred. The fantasy as a form that cannot be associated with the crystallized scheme became for V.A. Mozart an ideal opportunity to embody the content of a preromantic type. The dynamics of the artistic world of the fantasies by V.A. Mozart is in a gradual exacerbation of contrasts, increasing tensions of figurative comparisons of artistic and semantic development.

J. Haydn created the only work in the genre of fantasy - Fantasy C-dur (in 1789). The genre of fantasy in J. Haydn's composition was not the embodiment of forebodings of a romantic imagery [6], but the composition of the composer uniquely expresses the romantic standard. The music of the late J. Haydn's creativity multidimensionally anticipates the psychologically complex artistic world of the romantic era. The 18th - early 19th centuries - it is the era of a radical transformation of the genre of the fantasy. The fantasy manifested itself as a special type of compositions, possessing both specific stable features and moving, changing characteristics.

One of the students of V.A. Mozart, who achieved European fame and celebrity, is J.N. Hummel. The composer's appeal to the genre of the fantasy is not accidental. The fantasies of the composer are the most significant compositions in the piano heritage of J.N. Hummel. The appeal to the fantasy genre, in the development of which he was an unsurpassed master, is associated with the 19th century and covers almost a quarter-century period (the first piano Fantasy Es-dur op. 18 written in 1805, the last - C-dur op. 124 - dated 1833).

Hummel's interpretation of the fantasy genre, in addition to inheriting all the previous experience of creating such compositions, reflects the new laws that emerged in the 19th century. One of the manifestations in the work by J.N. Hummel of the innovative approach to the development of the genre becomes the emergence of fantasies on the borrowed topics. Apparently, the composer was one of the first in the Viennese classical school to create fantasies not only on the original material, but also on the borrowed topics, becoming one of the pioneers of the genre. Consequently, the preromantic tendency found in the interpretations of the fantasy genre in the creative heritage of V.A. Mozart and J. Haydn is confirmed by J.N. Hummel's special kind of the fantasy - the fantasy on the borrowed topics. However, the piano Fantasy Es-dur op. 18 and Rondo una fantasia op. 19 E-dur, which are the first examples of the genre of the fantasy in the creative heritage of the composer, should be attributed to the number of fantasies written on the original themes.

Since romanticism does not create unambiguous concepts, the subject of the fantasy contemplation for J.N. Hummel in Fantasy for piano op. 18 is not only the 
content, but also the principles of forming which are peculiar to the studied genre. In the work of Rondo una fantasia op. 19 E-dur, written in 1806, the genre synthesis declared by J.N. Hummel is already at the level of the genre name of the composition.

The genre of the fantasy is one of the constants in the works of L. Beethoven. The composer's piano fantasies received coverage in the scientific literature in connection with the study of L. Beethoven's piano sonatas. A number of works is devoted to the research of the sonatas "quasi una Fantasia" op. 27 No. 1 and No. 2, and among those works there are the works by B. Asafiev [1], V. Bobrovsky [2], Y. Kremlev [4], A. Goldenweiser [3], L. Reshetnikov [8]. Some information about Beethoven's Piano Fantasia, Op. 77 is contained in foreign studies $[9 ; 10]$. The task of periodization of L. Beethoven's mastery of the fantasy genre coincides with the division of the composer's creative works into periods generally accepted in the scientific literature ("three styles"). The early period of L. Beethoven's creative work is represented by Sonatas "quasi una Fantasia" op. 27 No. 1 and No. 2 (1800-1801), the central period - by Piano fantasy op. 77 and Fantasy for the piano, orchestra and choir op. 80 (1808-1809), the later period - by Sonatas for piano op. 101, op. 106, op. 109, op. 110, op. 111 (1816-1822). Although in the last five Sonatas their author's definition of them as the fantasies is absent, nevertheless there is a research interpretation of them as the fantasy sonatas [5].

Developing the Mozart tradition of combining the fantasies and sonatas, L. Beethoven created Sonatas op. 27 in 1800-1801 No. 1 and No. 2 which are the first examples of reference to the genre of fantasy in the composer's piano music. The author provides them with a general genre definition of "Sonata quasi una Fantasia", based on the interaction of two definitions - "Sonata" and "Fantasy", the result of which was a new synthetic genre name. Having created Fantasy for the piano, orchestra and choir op. 80, L. Beethoven refers to the interpretation of the fantasy genre as an independent composition. This composition is a harbinger of symphonic fantasies typical for the Romantic era. The piano Fantasy by J.N. Hummel op. 18 (1805) turned out to be a kind of the prototype of Fantasy for piano or. 77 by L. Beethoven or, more precisely, the Beethoven fantasy became a kind of the response to the composition by J.N. Hummel. Fantasy op. 77 is one of the few examples of compositions in which L. Beethoven, following the abruptly changing moods, unites them. Despite the abundance and diversity of themes, this fantasy maintains inner unity, reflecting the process of the consistent development of thoughts, feelings and moods. If in Fantasy for the piano with choir and orchestra op. $80 \mathrm{~L}$. Beethoven embodies the grandeur of the plan in the genre sample monumental in scale and content, the creation of Piano Fantasy op. 77 is associated with proximity to the type of interpretation of the genre, developed in the creative work of V.A. Mozart and J.N. Hummel.

The fantasy in the art of the Viennese classics contains a whole range of artistic discoveries that served as the basis for anticipating the principles of romantic art concerning the interpretation of the fantasy genre. In the creative work of V.A. Mozart and J. Haydn the piano fantasies were created on original themes, and 
only J.N. Hummel's and L. Beethoven's fantasies return the type of the genre interpretation typical for the fantasy of the 16th century - the processing of vocal and vocal-instrumental pieces. At the same time, J.N. Hummel's and L. Beethoven's piano fantasies, in addition to anticipating interpretations of the fantasy of the Romantic era, are also a generalization of the history of the development of the genre, inheriting not only the Baroque traditions, but also the traditions of V.A. Mozart and J. Haydn. The genre synthesis as a method immanently inherent in the genre of the fantasy, in the piano works of the Viennese classics acquires a peculiar embodiment.

\section{References:}

1. Asaf'ev B. V. (1981). Bethoven. Sonaty [Beethoven. Sonatas]. O simfonicheskoj i kamernoj muzyke. Pojasnenija i prilozhenija k programmam simfonicheskih i kamernyh koncertov [About symphonic and chamber music. Explanations and supplements to symphony and chamber concert programs]. Leningrad: Music, pp. 50-54.

2. Bobrovskij V. P. (1990). Sonata Bethovena "Quasi una Fantasia" cis-moll ("Lunnaja") [Sonata of Beethoven "Quasi una Fantasia" cis-moll ("Lunar")]. Stat'i i issledovanija [Articles and researches]. Moscow: Soviet composer, pp. 95-119.

3. Gol'denvejzer A. B. (1966). 32 sonaty Bethovena [32 sonatas of Beethoven]. Moscow: Music. (in Russian)

4. Kremlev Ju. (1970). Fortepiannye sonaty Bethovena [Beethoven's Piano Sonatas]. Moscow: Soviet composer. (in Russian)

5. Nikolaeva N. (1960). Bethoven i romantizm [Beethoven and Romanticism]. Journal Soviet music, vol. 12, pp. 44-56.

6. Palazhchenko I.R. (1992). Instrumental'naja fantazija XVII-XVIII vekov (genezis i puti razvitija) [Instrumental fantasy of the XVII-XVIII centuries (genesis and ways of development)] (PhD Thesis), Moscow.

7. Protopopov V. (1979). Ocherki iz istorii instrumental'nyh form XVI - nachala XIX veka [Essays from the history of instrumental forms of the XVI - early XIX century]. Moscow: Music. (in Russian)

8. Reshetnikov L. (1973). Storinka tvorchosti Bethovena [Beethoven's page of creativity]. Journal Music, vol. 4, p. 32.

9. Schulze Sean A neglected opus: an examination of the structural procedures employed in Beethoven`s "Fantaisie pour le pianoforte" op. 77 / Sean Schulze // The Beethoven journal / San Jose State University 2004. - № 19. - S. 66-71.

10. Schulze Sean (1999). An ignored fantasy: an examination of Beethoven's fantasy for piano op. 77, Diss. (DMA), Tucson, Aris, University of Arizona.

11. Shtrifanova K.V. (2007). Fantazija dlja ljutni XVI stolittja: stanovlennja zhanru [Fantasy for the lunar XVI century: the formation of the genre] (PhD Thesis), Kharkiv: Kharkiv National Kotlyarevsky University of Arts. 